\section{Germination of tucumã (Astrocaryum aculeatum G. Mey.) as a function of thermal pretreatment and stratification temperature}

\author{
Sidney Alberto do Nascimento Ferreira ${ }^{1 *}$ (D), Nelson Felipe de Albuquerque \\ Lins Neto ${ }^{2}$ (D), Daniel Felipe de Oliveira Gentil ${ }^{3}$
}

\begin{abstract}
Germination of tucumã (Astrocaryum aculeatum G. Mey.) seeds is slow and although the removal of the endocarp favors the speed of the process, the time is still considered long. Thus, this study aimed to investigate the effects of different pretreatment and stratification temperatures on the germination of tucumã seeds. Two experiments were set up. The first experiment was conducted using a completely randomized design in a factorial scheme and seedling emergence was evaluated as a function of the pretreatment of diaspores at different temperatures $\left(27,30,35\right.$, and $\left.40{ }^{\circ} \mathrm{C}\right)$ during different periods $(20$, 40 , and 60 days). The second experiment was also conducted in a completely randomized design and seed germination was evaluated as a function of seed stratification at constant $\left(25,30,35\right.$, and $\left.40{ }^{\circ} \mathrm{C}\right)$ and alternating temperatures ( $26-30,26-35$, and $\left.26-40{ }^{\circ} \mathrm{C}\right)$. Germination decreased progressively in all tested periods as the pretreatment temperature increased. Seed stratification at different constant and alternating temperatures showed different results. The pretreatment of diaspores at different temperatures for different periods was not effective in overcoming the dormancy of tucumã seeds. Seed stratification at alternating temperatures, with the highest thermal amplitude $\left(26-40{ }^{\circ} \mathrm{C}\right)$, favored the overcoming of dormancy and the germination of tucumã seeds.
\end{abstract}

Index terms: Arecaceae, seed dormancy, pre-germination treatments.

\section{Germinação de tucumã (Astrocaryum aculeatum G. Mey.) em função do pré-tratamento térmico e da temperatura de estratificação}

RESUMO: A germinação de sementes de tucumã (Astrocaryum aculeatum G. Mey.) é demorada e, embora a remoção do endocarpo favoreça a celeridade do processo, o tempo ainda é considerado longo. Assim, o objetivo deste trabalho foi investigar os efeitos de diferentes temperaturas de pré-tratamento e da estratificação sobre a germinação de sementes de tucumã. Foram instalados dois experimentos. No primeiro, utilizando o delineamento inteiramente ao acaso (DIC), em esquema fatorial, avaliou-se a emergência de plântulas em função do pré-tratamento dos diásporos em diferentes temperaturas $\left(27,30,35\right.$ e $\left.40{ }^{\circ} \mathrm{C}\right)$, por diferentes períodos (20, 40 e 60 dias). No outro, adotando o DIC, avaliou-se a germinação das sementes em função da estratificação das sementes em temperaturas constantes $(25,30,35$, $40^{\circ} \mathrm{C}$ ) e alternadas $\left(26-30,26-35\right.$ e $\left.26-40^{\circ} \mathrm{C}\right)$. A germinação, em todos os períodos testados, decresceu progressivamente à medida que se elevou a temperatura de pré-tratamento. A estratificação das sementes em diferentes temperaturas constantes e alternadas apresentaram resultados distintos. O pré-tratamento dos diásporos em diferentes temperaturas, por diferentes períodos, não foi eficaz na superação da dormência de sementes de tucumã. A estratificação das sementes em temperatura alternada, com maior amplitude térmica $\left(26-40{ }^{\circ} \mathrm{C}\right)$, favoreceu à superação da dormência e à germinação das sementes de tucumã.

Termos para indexação: Arecaceae, dormência de sementes, tratamentos pré-germinativos.
Journal of Seed Science, v.43, e202143007, 2021

http://dx.doi.org/10.1590/ 2317-1545v43230606
${ }^{*}$ Corresponding author
E-mail: sanf@inpa.gov.br

Received: $10 / 31 / 2019$ Accepted: 11/18/2020.

${ }^{1}$ Coordenação de Biodiversidade, Instituto Nacional de Pesquisas da Amazônia, Caixa Postal 2223, 69080-971 - Manaus, AM, Brasil.

${ }^{2}$ Faculdade Salesiana Dom Bosco, 69084-425 - Manaus, AM, Brasil.

${ }^{3}$ Faculdade de Ciências Agrárias, Universidade Federal do Amazonas, 69077-000 - Manaus, AM, Brasil. 


\section{INTRODUCTION}

Tucumã (Astrocaryum aculeatum G. Mey.) is a palm tree that occurs in the central and western Amazon, whose fruit pulp is highly appreciated by local populations both for fresh consumption and for the production of ice cream, sweets, juice, and liquor, being also used in animal feed. The demand for fruits is mostly supplied by the semi-extractive activity due to the small number of commercial plantations. The propagation of the species is performed exclusively by seeds, which present long germination due to dormancy (Ferreira and Gentil, 2006).

According to Baskin and Baskin (2014), seed dormancy can be classified as endogenous (morphological, physiological, or morphophysiological) when related to the embryo, exogenous (physical) when related to other diaspore structures, and combinatorial (physical and physiological). These authors also observed that water impermeability is the cause of physical dormancy, while the mechanical limitation is due to physiological dormancy, as embryo growth is sufficient to overcome the restrictive structures of the diaspore after overcoming the physiological dormancy.

Germination of tucumã seeds from the diaspore can take up to three years to occur (Koebernik, 1971). According to Gentil and Ferreira (2005), the presence of the hard endocarp may be related to restrictions on the germination of seeds of this species, as its removal favors the speed of the process, with a mean germination time (germinative bud formation) of 107 days and complete expansion of the first eophyll of 253 days. However, the time for germination is still long despite the benefits obtained with seed extraction, denoting the existence of other factors still unknown that condition the germination.

The use of high temperatures has been the focus of many studies related to overcoming dormancy in palm seeds. Thermal pretreatment is a common method for oil palm seeds (Elaeis guineensis), which have germination favored by temperatures between 38 and $42^{\circ} \mathrm{C}$ for 30 to 80 days (Rees, 1962; Comont and Jacquemard, 1977; Fondom et al., 2010; Green et al., 2013; Green et al., 2019). According to Jiménez et al. (2008), the marked reduction in the endogenous concentration of abscisic acid in oil palm embryos is an important factor in overcoming dormancy through heat $\left(40{ }^{\circ} \mathrm{C}\right.$ for 50 days), although the function of 3-indole acetic acid and changes in sensitivity to plant hormones cannot be ruled out.

Warm stratification is another method that has been successful in suppressing dormancy in palm seeds. FinchSavage and Leubner-Metzger (2006) mentioned the need for warm stratification to overcome dormancy in seeds with small but fully developed embryos, which is associated with the decline in the concentration of abscisic acid. Favorable results have been observed at constant temperatures of 25 to $35{ }^{\circ} \mathrm{C}$ in Pritchardia remota (Pérez et al., 2008) and alternating temperatures of $25-40{ }^{\circ} \mathrm{C}$ in Rhapidophyllum hystrix (Carpenter et al., 1993) and $26-40{ }^{\circ} \mathrm{C}$ in Bactris maraja (Rodrigues et al., 2014) and Phytelephas macrocarpa (Ferreira and Gentil, 2017).

Palm seeds generally require high temperatures for fast and uniform germination, considering temperatures in the range from 21 to $38{ }^{\circ} \mathrm{C}$ as acceptable and 29 to $35{ }^{\circ} \mathrm{C}$ as more favorable (Meerow and Broschat, 2017). Some species benefit from constant temperatures, such as Sabal etonia $\left(24\right.$ to $\left.36^{\circ} \mathrm{C}\right)$, Coccothrinax argentata and Thrinax morrisii ( 33 to $36^{\circ} \mathrm{C}$ ), and Acoelorrhaphe wrightii (33 to $\left.39^{\circ} \mathrm{C}\right)$ (Carpenter, 1988), while others benefit from alternating temperatures, such as Phoenix canariensis $\left(20-30\right.$ and $\left.25-35^{\circ} \mathrm{C}\right)$ (Pimenta et al., 2010) and Attalea vitrivir $\left(20-30^{\circ} \mathrm{C}\right)$ (Neves et al., 2013).

Nazário and Ferreira (2010) found that soaking tucumã seeds at a temperature of $40{ }^{\circ} \mathrm{C}$ for four days reduced the mean time for the emergence of the second cataphile (163 days). Furthermore, Ferreira et al. (2010) found that sowing in wood sawdust inside mini-greenhouses maintained under 30 and $50 \%$ shadows favored the seed germination process because these environments provide higher thermal amplitudes and reach higher temperatures throughout the day. Therefore, considering the promising results that demonstrate the positive influence of high temperatures on the germination of tucumã seeds, this study was carried out to investigate the effects of different pretreatment and stratification temperatures on seed germination of this species. 


\section{MATERIAL AND METHODS}

The diaspores used in this study came from ripe fruits obtained in Manaus, State of Amazonas, Brasil, being characterized as a mixture of half-sibling progenies derived from fruits of various racemes and plants. Cleaning was carried out to remove the rest of the pulp adhering to the endocarp through the initial immersion in water for three days, followed by rubbing with sand and washing in running water, according to the procedure adopted by Ferreira and Gentil (2006). Diaspores with a diameter of lower than $3.5 \mathrm{~cm}$ and higher than $4.5 \mathrm{~cm}$ were discarded during this process to avoid that marked differences in the size of diaspores and/or thickness of endocarps interfere with the response to the tested temperatures.

\section{Experiment 1. Germination as a function of the thermal pretreatment of diaspores}

After cleaning, the diaspores were shade-dried under ambient conditions (mean compensated temperature of $27{ }^{\circ} \mathrm{C}$ and relative humidity of $74.13 \%$ ) for 48 hours, reaching a water content of $29.4 \%$. The water content was determined by the oven method at $105 \pm 3{ }^{\circ} \mathrm{C}$ for 24 hours (Brasil, 2009), with four replications of five units each.

Subsequently, the diaspores were packed in two transparent polyethylene bags (one inside the other) closed individually and subjected to temperatures of 27 (mean compensated temperature under ambient conditions and without light), 30,35 , and $40{ }^{\circ} \mathrm{C}$ for 20,40 , and 60 days. The temperatures of 30,35 , and $40{ }^{\circ} \mathrm{C}$ were obtained in controlled ovens without light.

After each period, the diaspores were transferred to mesh polyethylene bags and kept in a controlled environment (mean temperature of $23.5^{\circ} \mathrm{C}$ and relative air humidity of $64.4 \%$ ) for fifteen days, which allowed the loss of moisture and, therefore, the detachment of the seeds from the endocarp. Then, the seeds were extracted and soaked in water for nine days (Ferreira and Gentil, 2006), followed by sowing.

Sowing was performed in high-density polyethylene boxes $(60 \times 41 \times 18 \mathrm{~cm})$ filled with wood sawdust as a substrate, covered with agro-film (100 micra), forming a mini-greenhouse (Ferreira et al., 2010) with a minimum mean temperature of $26.2 \pm 1.3^{\circ} \mathrm{C}$ and a maximum mean temperature of $40.7 \pm 4.5^{\circ} \mathrm{C}$, measured periodically using a maximum and minimum thermometer. The boxes were maintained in a nursery covered with a $50 \%$ shade screen. At sowing, the germination pore was positioned at an angle of $90^{\circ}$ relative to an imaginary axis perpendicular to the substrate.

Seedling emergence was counted for six months every ten days and the data were later transformed into percentages, which allowed the calculation of the emergence speed index (ESI), as described by Ranal and Santana (2006). Dead and dormant seeds were identified by the cut test at the end of the experiment from non-germinated seeds (Brasil, 2009).

The experimental design was completely randomized in a $3 \times 4$ factorial scheme, consisting of three pretreatment periods and four pretreatment temperatures, with four replications containing 25 seeds each. The percentage values (emergence, dead seeds, and dormant seeds) were transformed into $\sqrt{\frac{x+0.5}{100}}$ and the ESI values were transformed into $\sqrt{x+0.5}$ aiming at data normalization. The data were subjected to analysis of variance to estimate the effects of each factor and the interaction between factors. Considering that the levels of factors (treatments) were quantitative and that all variables had an effect of interaction between factors, regression studies were carried out taking into account each level of the factor period $(20,40$, and 60 days) as a function of the thermal pretreatment temperatures $\left(27,30,35\right.$, and $40^{\circ} \mathrm{C}$ ). The analyses were performed using the software ASSISTAT 7.7 (Silva and Azevedo, 2016). The results were presented and discussed based on the original data.

\section{Experiment 2. Germination as a function of the stratification temperature of seeds}

After cleaning, the diaspores were maintained under ambient conditions (mean temperature of $28.7 \pm 1.4{ }^{\circ} \mathrm{C}$ and mean relative humidity of $76.0 \pm 6.9 \%$ ) for six months. Then, the seeds were extracted and soaked in water for nine days (Ferreira and Gentil, 2006), reaching a water content of $27.6 \%$. The water content was determined by the oven 
method at $105 \pm 3^{\circ} \mathrm{C}$ for 24 hours (Brasil, 2009), with four replications of five seeds broken in half.

Subsequently, the seeds were placed in transparent polyethylene bags ( $29 \times 16 \mathrm{~cm}$ and $0.075 \mathrm{~mm}$ thick) containing thick texture vermiculite at the same proportion of the seed volume ( 25 units) moistened with water equivalent to $60 \%$ of its dry mass. The bags were closed and placed in chambers (in the absence of light) at temperatures of 25, 30, 35, 40, $26-30,26-35$, and $26-40^{\circ} \mathrm{C}$. A timer was used to trigger the temperature rise at nine o'clock and turn it off at fifteen o'clock for the alternating temperatures; the internal temperature of the chamber was reduced during the rest of the time in a 24-hour cycle, reaching the mean minimum temperature of $26^{\circ} \mathrm{C}$.

Germination was evaluated every thirty days for four months, being considered as germinated the seed with the developed germinative bud (Queiroz, 1986; Ferreira and Gentil, 2006; Ferreira and Gentil, 2017; Cui et al., 2020). The substrate (vermiculite) was sprayed with water after each germination count and before the bags were closed again aiming to maintain its moisture. Seeds that did not germinate at the end of the experiment were classified as dead or dormant using the cut test (Brasil, 2009). The germination speed index (GSI) was calculated according to Ranal and Santana (2006).

The experimental design was completely randomized with seven treatments (temperatures) and four replications of 25 seeds. The percentage values (germination, dead seeds, and dormant seeds) were transformed into $\operatorname{arcsine} \sqrt{\frac{x+0.5}{100}}$ and the GSI values were transformed into $\sqrt{x+0.5}$ aiming at data normalization. The treatment means were compared by the Tukey test at a $5 \%$ probability level after the analysis of variance. The analyses were performed using the software ASSISTAT 7.7 (Silva and Azevedo, 2016). The results were presented and discussed based on the original data.

\section{RESULTS AND DISCUSSION}

\section{Experiment 1. Germination as a function of the thermal pretreatment of diaspores}

The studied variables had significant interaction effects between the factors temperature and pretreatment period (Table 1). The emergence decreased progressively in all periods $(20,40$, and 60 days) as the pretreatment temperature increased (Figure 1A). This decrease was less pronounced when the period was only twenty days. On the other hand, the emergence was zero at a temperature of $40^{\circ} \mathrm{C}$ in the longest periods ( 40 and 60 days). Emergence was negatively affected by the highest temperatures $\left(35\right.$ and $\left.40^{\circ} \mathrm{C}\right)$, regardless of the pretreatment periods.

Seed mortality showed a behavior virtually opposite to that of emergence, that is, it increased with an increase in the pretreatment temperature (Figure 1B). This increase was lower when the period was 20 days and reached a maximum value (100\%) in the periods of 40 and 60 days, with a temperature of $40{ }^{\circ} \mathrm{C}$. The highest percentages of

Table 1. Summary of analysis of variance for the variables emergence, mortality, dormancy, and emergence speed index (ESI) referring to tucumã (Astrocaryum aculeatum G. May.) diaspores submitted to different periods $\left(20,40\right.$, and 60 days) and pretreatment temperatures $\left(27,30,35\right.$, and $\left.40^{\circ} \mathrm{C}\right)$.

\begin{tabular}{cccccc}
\hline \multirow{2}{*}{ Source of variation } & \multirow{2}{*}{ DF } & \multicolumn{4}{c}{ Mean square } \\
\cline { 3 - 6 } & & Emergence & Mortality & Dormancy & ESI \\
\hline Period $(\mathrm{P})$ & 2 & $790.84^{* *}$ & $1270.70^{* *}$ & $672.50^{* *}$ & $0.003^{*}$ \\
Temperature $(\mathrm{T})$ & 3 & $3228.63^{* *}$ & $4706.45^{* *}$ & $246.60^{* *}$ & $0.019^{* *}$ \\
Interaction $\mathrm{P} \times \mathrm{T}$ & 6 & $287.00^{* *}$ & $440.07^{* *}$ & $81.25^{* *}$ & $0.002^{*}$ \\
Residual & 36 & 38.08 & 46.11 & 23.31 & 0.001 \\
\hline $\mathrm{CV}(\%)$ & - & 15.97 & 13.94 & 40.12 & 3.05 \\
\hline
\end{tabular}

* and ${ }^{* *}$ : significant by the F-test at 5 and $1 \%$ probability levels, respectively; DF: degrees of freedom; CV: coefficients of variation. 

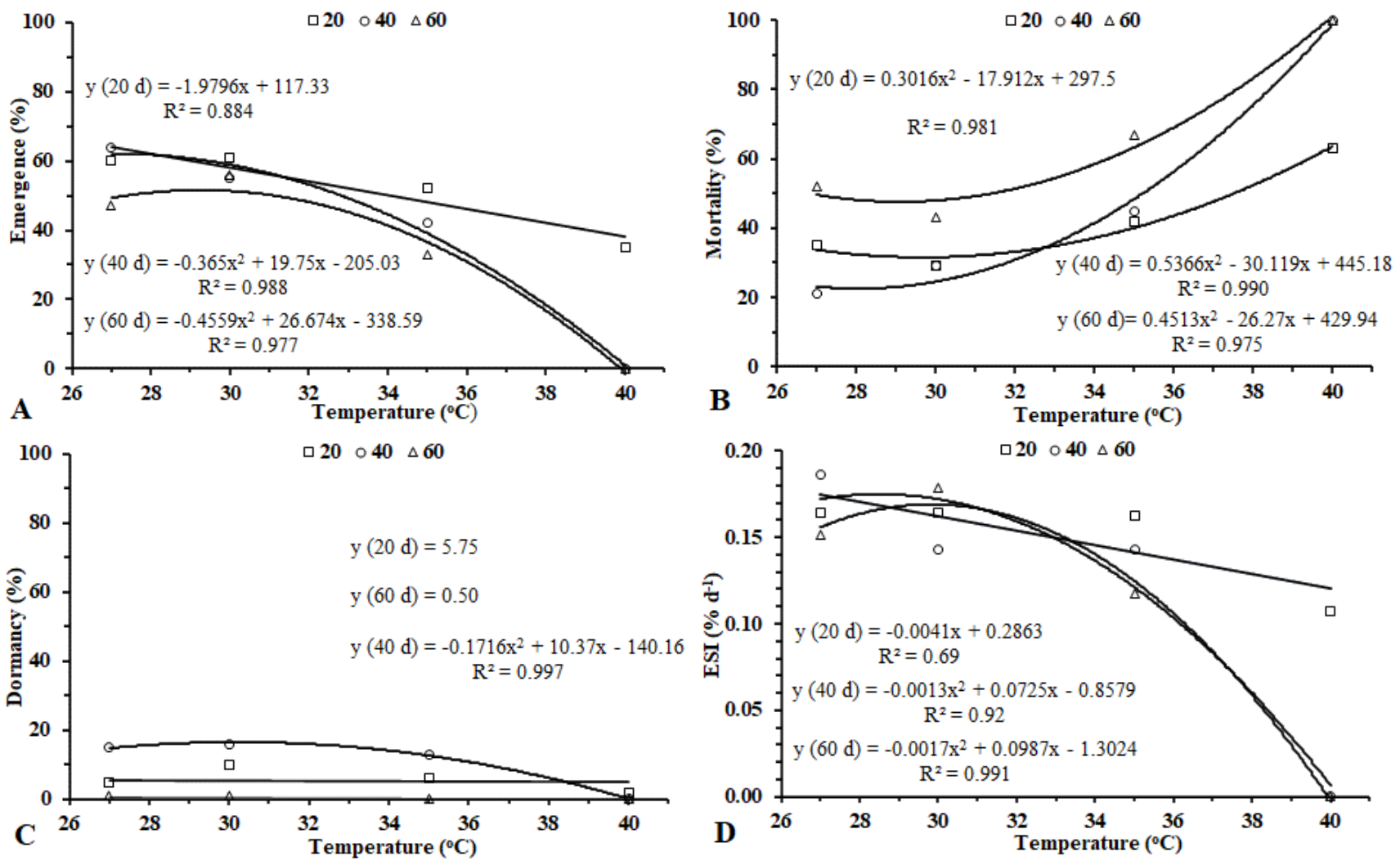

Figure 1. Emergence (A), mortality (B), dormancy (C), and emergence speed index (ESI) (D) referring to the effect of the interaction between periods $\left(20,40\right.$, and 60 days) and pretreatment temperatures $\left(27,30,35\right.$, and $\left.40{ }^{\circ} \mathrm{C}\right)$ of tucumã (Astrocaryum aculeatum G. May.) diaspores.

dormancy (around $15 \%$ ) were observed at temperatures of 27,30 , and $35{ }^{\circ} \mathrm{C}$ for the period of 40 days of pretreatment, but the values were lower under the other conditions (Figure 1C).

The emergence speed index showed a behavior similar to that of the emergence, decreasing with an increase in the pretreatment temperature of diaspores, although less accentuated when applied for only 20 days (Figure 1D). The decrease was more accentuated in the longest pretreatment periods ( 40 and 60 days), reaching zero at a temperature of $40^{\circ} \mathrm{C}$.

The germination of tucumã seeds was impaired by pretreatment at temperatures of 35 and $40^{\circ} \mathrm{C}$ for 20,40 , and 60 days. Also, the temperature of $30^{\circ} \mathrm{C}$ did not present an advantage as a pretreatment when compared to the ambient temperature of $27^{\circ} \mathrm{C}$, regardless of the period.

Despite these results, it seems convenient to continue investigating the effects of thermal pretreatment on tucumã seeds, as many factors may be involved. According to Orozco-Segovia et al. (2003) and Meerow and Broschat (2017), variations in the germinability of palm seeds occur due to the genotype, maturation stage, and seed management. Although pretreatment is used routinely in oil palm (Elaeis guineensis), recent studies have shown variations as a function of the genotype, seed water content, temperature, and time of exposure (Fondom et al., 2010; Guerrero et al., 2011; Green et al., 2013; Lima et al., 2014; Green et al., 2019).

\section{Experiment 2. Germination as a function of the stratification temperature of seeds}

The evaluated variables had a significant effect relative to the used stratification temperatures (Table 2). Thus, the stratification temperatures of $25,30,35,26-30$, and $26-35^{\circ} \mathrm{C}$ were not favorable to overcome the dormancy of tucumã seeds, as most of the seeds remained dormant or died, leading to a low percentage of germination (Table 3). According to Carpenter (1988), temperatures out of the optimum level contribute to long periods of irregular germination and a low percentage. 
Table 2. Summary of analysis of variance for the variables germination, mortality, dormancy, and germination speed index (GSI) referring to tucumã (Astrocaryum aculeatum G. May.) seeds stratified under different temperatures regimes $\left(25,30,35,40,26-30,26-35\right.$, and $\left.26-40^{\circ} \mathrm{C}\right)$.

\begin{tabular}{cccccc}
\hline \multirow{2}{*}{ Source of variation } & \multirow{2}{*}{ DF } & \multicolumn{5}{c}{ Mean square } \\
\cline { 3 - 6 } & & Germination & Mortality & Dormancy & GSI \\
\hline Treatment & 6 & $1302.24^{* *}$ & $796.76^{* *}$ & $718.10^{* *}$ & $0.248^{* *}$ \\
Residual & 21 & 80.65 & 81.06 & 55.95 & 0.026 \\
\hline CV (\%) & - & 30.93 & 23.10 & 22.64 & 16.20 \\
\hline
\end{tabular}

**: significant by the F-test at a 1\% probability level; DF: degrees of freedom; CV: coefficients of variation.

Table 3. Germination, mortality, dormancy, and germination speed index (GSI) referring to tucumã (Astrocaryum aculeatum G. May.) seeds at different temperature regimes.

\begin{tabular}{ccccc}
\hline Temperature $\left({ }^{\circ} \mathrm{C}\right)$ & Germination (\%) & Mortality (\%) & Dormancy (\%) & ${\text { GSI }\left(\% \text { day }^{-1}\right)}^{25}$ \\
\hline 25 & $27 \mathrm{bc}$ & $33 \mathrm{~b}$ & $40 \mathrm{a}$ & $0.556 \mathrm{~b}$ \\
30 & $18 \mathrm{bcd}$ & $44 \mathrm{~b}$ & $37 \mathrm{ab}$ & $0.322 \mathrm{~b}$ \\
35 & $7 \mathrm{~cd}$ & $34 \mathrm{~b}$ & $59 \mathrm{a}$ & $0.100 \mathrm{~b}$ \\
40 & $0 \mathrm{~d}$ & $84 \mathrm{a}$ & $16 \mathrm{bc}$ & $0.000 \mathrm{~b}$ \\
$26-30$ & $31 \mathrm{~b}$ & $26 \mathrm{~b}$ & $40 \mathrm{a}$ & $0.536 \mathrm{~b}$ \\
$26-35$ & $35 \mathrm{~b}$ & $31 \mathrm{~b}$ & $33 \mathrm{ab}$ & $0.670 \mathrm{~b}$ \\
$26-40$ & $73 \mathrm{a}$ & $23 \mathrm{~b}$ & $4 \mathrm{c}$ & $1.722 \mathrm{a}$ \\
\hline
\end{tabular}

Means followed by the same letter in the column do not differ significantly from each other by the Tukey test at a $5 \%$ probability level.

The worst germination performance was observed at the constant temperature of $40^{\circ} \mathrm{C}$, which also had the highest seed mortality (Table 3), as observed in the previous experiment. The use of the constant temperature of $40{ }^{\circ} \mathrm{C}$ in other palms was equally harmful to seed germination, such as in Rhapidophyllum hystrix (Carpenter et al., 1993) and Archontophoenix alexandrae (Teixeira et al., 2011). However, the temperature of $40{ }^{\circ} \mathrm{C}$ was beneficial for Butia odorata only when used in a short period (21 days) (Schlindwein et al., 2013), showing that the response to high temperatures may be related to the combination between temperature and time of exposure. Optionally, high temperatures can be used by alternation (Carpenter et al., 1993; Pimenta et al., 2010; Neves et al., 2013; Rodrigues et al., 2014; Ferreira and Gentil, 2017) or succession (Schlindwein et al., 2013) with relatively lower temperatures.

Although high temperatures are necessary to overcome dormancy in warm stratification, the permanence of palm seeds at constant high temperatures may not be suitable for germination (Orozco-Segovia et al., 2003) and/or seedling development (Pérez et al., 2008). In these cases, germination corresponds to the formation of the germinative bud (cotyledonary petiole), while plant growth is part of post-germinative events (Cui et al., 2020).

The stratification temperature of $26-40^{\circ} \mathrm{C}$ had a better germinative result for tucumã seeds, with low percentages of dormant and dead seeds (Table 3), similarly to what was verified in seeds of other Amazonian palms (Rodrigues et al., 2014; Ferreira and Gentil, 2017). The germination speed was also higher at this temperature, differing significantly from the others, which demonstrates its positive effect on overcoming dormancy and on the germination of tucumã seeds. The effect of stratification at $26-40{ }^{\circ} \mathrm{C}$ is likely related not only to the daily temperature fluctuations but also to the highest provided temperature $\left(40^{\circ} \mathrm{C}\right)$ and the highest achieved thermal amplitude $\left(14{ }^{\circ} \mathrm{C}\right)$. Ferreira et al. (2010) also found that higher thermal amplitudes $\left(13\right.$ and $14{ }^{\circ} \mathrm{C}$ ) and higher mean daily temperatures $\left(38\right.$ and $\left.39{ }^{\circ} \mathrm{C}\right)$ in mini-greenhouses favored the germinative process of tucumã seeds. The thermal pretreatment at $40{ }^{\circ} \mathrm{C}$ even though 
required in oil palm (Elaeis guineensis) to overcome dormancy, the higher daily thermal amplitude is an important factor in germination (Norsazwan et al., 2020).

High temperatures seem to have some effect in overcoming seed dormancy in some palm trees (Rees, 1962; Comont and Jacquemard, 1977; Carpenter et al., 1993; Fondom et al., 2010; Guerrero et al., 2011; Green et al., 2013; Schlindwein et al., 2013; Lima et al., 2014; Rodrigues et al., 2014; Ferreira and Gentil, 2017; Green et al., 2019). Some associations between high temperatures and the physiological effect on seed dormancy have been pointed out, such as the reduction in the concentration of abscisic acid in the embryo and endosperm (Finch-Savage and Leubner-Metzger, 2006; Jiménez et al., 2008), the alteration in the balance between abscisic acid and other plant hormones (Cui et al., 2020), and changes in sensitivity to plant hormones (Jiménez et al., 2008). According to Yan and Chen (2017), abscisic acid plays an essential role in the regulation of seed dormancy, and any suppression of its activity or changes in sensitivity to it, directly or indirectly, can cause changes in the states of dormancy and eventually lead to seed germination.

Other occurrences are also considered in the relationship between high temperatures and palm seed germination, such as reaching the lipid melting point (Orozco-Segovia et al., 2003) and increasing the activity of enzymes that remove mechanical limitations to germination (Schlindwein et al., 2013). However, according to Yan and Chen (2017), seed germination is due to a series of events, including energy mobilization and cell wall modification, and ABA acts as an inhibitor of these processes. Thus, there is still much to be understood in the relationship between specific environmental conditions and the physiological mechanisms that trigger dormancy in palm seeds, including tucumã.

Finally, if the temperature of $26-40^{\circ} \mathrm{C}$ is used in tucumã seeds, germinated seeds are recommended to be removed from the stratification medium and transferred to the nursery, as indicated for other palm trees (Pérez et al., 2008; Ferreira and Gentil, 2017), as soon as they reach the developed germinative bud stage, aiming to avoid the occurrence of abnormalities in the seedlings.

\section{CONCLUSIONS}

The pretreatment of diaspores at different temperatures $\left(27,30,35\right.$, and $\left.40{ }^{\circ} \mathrm{C}\right)$ for different periods $(20,40$, and 60 days) was not effective in overcoming the dormancy of tucumã seeds.

Seed stratification at alternating temperatures, with higher thermal amplitude $\left(26-40^{\circ} \mathrm{C}\right)$, favored the overcoming of dormancy and germination of tucumã seeds.

\section{REFERENCES}

BASKIN, C.C.; BASKIN, J.M. Seeds: ecology, biogeography, and evolution of dormancy and germination. 2. ed. San Diego: Elsevier, 2014. 1586p.

BRASIL. Ministério da Agricultura, Pecuária e Abastecimento. Regras para análise de sementes. Brasília: Ministério da Agricultura, Pecuária e Abastecimento. Secretaria de Defesa Agropecuária. 2009. 395p. http:// www.agricultura.gov.br/arq_editor/file/2946_ regras_analise_sementes.pdf

CARPENTER, W.J. Temperature affects seed germination of four Florida palm species. HortScience, v.23, n.2, p.336-337, 1988.

CARPENTER, W.J.; OSTMARK, E.R.; RUPPERT, K.C. Promoting the rapid germination of needle palm seed. Proceedings of the Florida State Horticultural Society, v.106, p.336-338, 1993. https://journals.flvc.org/fshs/article/view/92708

COMONT, G.; JACQUEMARD, J.C. Germination des graines de palmier à huile (E. guineensis) em sacs de polyéthylène. Méthode par "charleur sèche". Oléagineux, v.32, n.4, p.149-151, 1977.

CUI, J.; LAMADE, E.; TCHERKEZ, G. Seed germination in oil palm (Elaeis guineensis Jacq.): a review of metabolic pathways and control mechanisms. International Journal of Molecular Sciences, v.21, n.4227, p.1-13, 2020. https://doi.org/10.3390/ijms21124227 
FERREIRA, S.A.N.; CASTRO, A.F.; GENTIL, D.F.O. Emergência de plântulas de tucumã (Astrocaryum aculeatum) em função do prétratamento das sementes e da condição de semeadura. Revista Brasileira de Fruticultura, v.32, n.4, p.1189-1195, 2010. http:// www.scielo.br/scielo.php?script=sci_arttext\&pid=S010029452010000400029\&lng=en\&nrm=iso\&tlng=pt

FERREIRA, S.A.N.; GENTIL, D.F.O. Extração, embebição e germinação de sementes de tucumã (Astrocaryum aculeatum). Acta Amazonica, v.36, n.2, p.141-146, 2006. http://www.scielo.br/scielo.php?script=sci_arttext\&pid=\$004459672006000200002\&lng=en\&nrm=iso\&tlng=pt

FERREIRA, S.A.N.; GENTIL, D.F.O. Seed germination at different stratification temperatures and development of Phytelephas macrocarpa Ruiz and Pavón seedlings. Journal of Seed Science, v.39, n.1, p.20-26, 2017. http://www.scielo.br/scielo.php?script=sci_ arttext\&pid=S2317-15372017000100020

FINCH-SAVAGE, W.E.; LEUBNER-METZGER, G. Seed dormancy and the control of germination. New Phytologist, v.171, p.501-523, 2006. https://nph.onlinelibrary.wiley.com/doi/epdf/10.1111/j.1469-8137.2006.01787.x

FONDOM, N.Y.; ETTA, C.E.; MIH, A.M. Breaking seed dormancy: revisiting heat-treatment duration on germination and subsequent seedling growth of oil palm (Elaeis guineensis Jacq.) progenies. Journal of Agricultural Science, v.2, n.2, p.101-110, 2010. http:// www.ccsenet.org/journal/index.php/jas/article/view/4402

GENTIL, D.F.O.; FERREIRA, S.A.N. Morfologia da plântula em desenvolvimento de Astrocaryum aculeatum Meyer (Arecaceae). Acta Amazonica, v.35, n.3, p.337-342, 2005 . http://www.scielo.br/scielo.php?script=sci_ arttext\&pid=S004459672005000300005\&lng=en\&nrm=iso\&tIng=pt

GREEN, M.; LIMA, W.A.A.; FIGUEIREDO, A.F.; ATROCH, A.L.; LOPES, R.; CUNHA, R.N.V.; TEIXEIRA, P.C. Heat-treatment and germination of oil palm seeds (Elaeis guineensis Jacq.). Journal of Seed Science, v.35, n.3, p.296-301, 2013. http://www.scielo.br/ scielo.php?script=sci_arttext\&pid=S2317-15372013000300004

GREEN, M.; LIMA, W.A.A.; LOPES, R. Umidade e aquecimento térmico na superação de dormência de sementes de dendezeiro tipo dura. Revista de Ciências Agrárias, v.62, p.1-6, 2019. https://ajaes.ufra.edu.br/index.php/ajaes/issue/view/89

GUERRERO, J.; BASTIDAS, S.; GARCÍA, J. Estandarización de una metodología para germinar semillas del híbrido interespecífico Elaeis oleifera H.B.K. x Elaeis guineensis J. Revista de Ciencias Agrícolas, v.28, n.1, p.132-146, 2011. http://revistas.udenar.edu.co/ index.php/rfacia/issue/view/11

JIMÉNEZ, V.M.; GUEVARA, E.; HERRERA, J.; ALIZAGA, R.; BANGERTH, F. Changes in hormone concentrations during dormancy release of oil palm (Elaeis guineensis) seeds. Seed Science and Technology, v.36, n.3, p.575-587, 2008. https://www.ingentaconnect.com/ content/ista/sst/2008/00000036/00000003/art00007

KOEBERNIK, J. Germination of palm seed. Principes, v.15, n.4, p.134-137, 1971.

LIMA, W.A.A.; LOPES, L.; GREEN, M.; CUNHA, R.N.V.; ABREU, S.C.; CYSNE, A.Q. Heat treatment and germination of seeds of interspecific hybrid between American oil palm (Elaeis oleifera (H.B.K) Cortes) and African oil palm (Elaeis guineensis Jacq.). Journal of Seed Science, v.36, n.4, p.451-457, 2014. http://www.scielo.br/pdf/jss/v36n4/a10v36n4.pdf

MEEROW, A.W.; BROSCHAT, T.K. Palm seed germination. University of Florida/IFAS Extension, BUL274, p.1-9, 2017. https://edis.ifas. ufl.edu/ep238

NAZÁRIO, P.; FERREIRA, S.A.N. Emergência de plântulas de Astrocaryum aculeatum G. May. em função da temperatura e do período de embebição das sementes. Acta Amazonica, v.40, n.1, p.165-170, 2010. http://www.scielo.br/scielo.php?script=sci_ arttext\&pid=S0044-59672010000100021\&lng=en\&nrm=iso\&tlng=pt

NEVES, S.C.; RIBEIRO, L.M.; CUNHA, I.R.G.; PIMENTA, M.A.P.; MERCADANTE-SIMÕES, M.O.; LOPES, P.S.N. Diaspore structure and germination ecophysiology of the babassu palm (Attalea vitrivir). Flora, v.208, n.1, p.68-78, 2013. https://www.sciencedirect.com/ journal/flora/vol/208/issue/1

NORSAZWAN, M.G.; SINNIAH, U.R.; PUTEH, A.B.; NAMASIVAYAM, P.; MOHAIMI, M.; AMINUDDIN, I.A. Temperature fluctuation improves oil palm (Elaeis guineensis) dura $\times$ pisifera seed germination. Seed Science and Technology, v.48, n.1, p.49-55, 2020. https://doi.org/10.15258/sst.2020.48.1.07

OROZCO-SEGOVIA, A.; BATIS, A.I.; ROJAS-ARÉCHIGA, M.; MENDOZA, A. Seed biology of palms: a review. Palms, v.47, n.2, p.79-94, 2003. http://www.palms.org/palmsjournal/2003/vol47n2p79-94.pdf 
PÉREZ, H.E.; CRILEY, R.A.; BASKIN, C.C. Promoting germination in dormant seeds of Pritchardia remota (Kuntze) Beck an endangered palm endemic to Hawaii. Natural Areas Journal, v.28, n.3, p.250-260, 2008. https://bioone.org/journals/natural-areas-journal/ volume-28/issue-3

PIMENTA, R.S.; LUZ, P.B.; PIVETTA, K.F.L.; CASTRO, A.; PIZETTA, P.U.C. Efeito da maturação e temperatura na germinação de sementes de Phoenix canariensis Hort. ex Chabaud - Arecaceae. Revista Árvore, v.34, n.1, p.31-38, 2010. http://www.scielo.br/pdf/rarv/ v34n1/v34n1a04.pdf

QUEIROZ, M.H. Botão germinativo do palmiteiro como indicador da germinação. Revista Brasileira de Sementes, v.8, n.2, p.55-59, 1986.

RANAL, M.A.; SANTANA, D.G. How and why to measure the germination process? Revista Brasileira de Botânica, v.29, n.1, p.1-11, 2006. http://www.scielo.br/pdf/rbb/v29n1/a02v29n1.pdf

REES, A.R. High-temperature pre-treatment and the germination of seed of the oil palm, Elaeis guineensis (Jacq.). Annals of Botany, v.26, n.4, p.569-581， 1962. http://aob.oxfordjournals.org/search?fulltext=Rees\%2C+A.R.+v.26\%2C+n.104\%2C+p.569$581 \% 2 C+1962 \&$ submit $=y e s \& x=0 \& y=0$

RODRIGUES, J.K.; MENDONÇA, M.S.; GENTIL, D.F.O. Efeito da temperatura, extração e embebição de sementes na germinação de sementes de Bactris maraja Mart. (Arecaceae). Revista Árvore, v.38, n.5, p.857-865, 2014. http://www.scielo.br/scielo. php?pid=S0100-67622014000500010\&script=sci_abstract\&tlng=pt

SCHLINDWEIN, G.; SCHLINDWEIN, C.C.D.; TONIETTO, A.; DILLENBURG, L.R. Alleviation of seed dormancy in Butia odorata palm tree using drying and most-warm stratification. Seed Science and Technology, v.41, n.1, p.16-26, 2013. http://www.ingentaconnect. com/contentone/ista/sst/2013/00000041/00000001/art00002?crawler=true

SILVA, F.A.S.; AZEVEDO, C.A.V. The Assistat software version 7.7 and its use in the analysis of experimental data. African Journal of Agricultural Research, v.11, n.39, p.3733-3740, 2016. https://academicjournals.org/journal/AJAR/article-full-textpdf/5E8596460818

TEIXEIRA, M.T.; VIEIRA, H.D.; PARTELLI, F.L.; SILVA, R.F. Despolpamento, armazenamento e temperatura na germinação de sementes de palmeira real australiana. Pesquisa Agropecuária Tropical, v.41, n.3, p.378-384, 2011. https://www.revistas.ufg.br/pat/issue/ view/1023

YAN, A.; CHEN, Z. The pivotal role of abscisic acid signaling during transition from seed maturation to germination. Plant Cell Reports, v.36, p.1-15, 2017. https://doi.org/10.1007/s00299-016-2082-z use, distribution, and reproduction in any medium, provided the original work is properly cited. 